\title{
ANALIS FAKTOR-FAKTOR YANG MEMPENGARUHI KEPATUHAN WAJIB PAJAK PADA KANTOR PELAYANAN PAJAK PRATAMA BULUKUMBA
}

\author{
ANALYSIS OF FACTORS INFLUENCING TAXPAYER \\ COMPLIANCE AT BULUKUMBA SMALL TAX OFFICE
}

\author{
Santuo \\ Kantor Pelayanan Pajak Pratama Bulukumba - Direktorat Jenderal Pajak \\ email: santo.statistika@gmail.com
}

\begin{abstract}
Abstrak
Kepatuhan wajib pajak dipengaruhi oleh beberapa faktor, beberapa diantaranya adalah pemahaman peraturan perpajakan wajib pajak, kualitas pelayanan fiskus dan pemeriksaan pajak. Penelitian ini bertujuan untuk mengetahui pengaruh pemahaman peraturan perpajakan wajib pajak, kualitas pelayanan fiskus dan pemeriksaan pajak terhadap kepatuhan wajib pajak pada Kantor Pelayanan Pajak Pratama Bulukumba. Jumlah sampel yang digunakan sebagai responden pada penelitian ini adalah sebanyak 100 wajib pajak pada Kantor Pelayanan Pajak Pratama Bulukumba. Teknik pengumpulan data menggunakan kuesioner. Analisis data menggunakan analisis regresi linear berganda dengan uji hipotesis parsial dan simultan. Hasil penelitian menunjukkan bahwa terdapat pengaruh yang positif dan signifikan pada pemahaman peraturan perpajakan wajib pajak, kualitas pelayanan fiskus dan pemeriksaan pajak terhadap kepatuhan wajib pajak. Hal ini berarti bahwa kepatuhan wajib pajak pada Kantor Pelayanan Pajak Pratama Bulukumba secara mayoritas dipengaruhi oleh pemahaman peraturan perpajakan wajib pajak, kualitas pelayanan fiskus dan pemeriksaan pajak serta selebihnya dipengaruhi oleh faktor lain yang tidak dimasukkan dalam model penelitian ini.
\end{abstract}

Kata Kunci: kepatuhan wajib pajak, pemahaman peraturan perpajakan, kualitas pelayanan fiskus, pemeriksaan pajak

\begin{abstract}
Taxpayer compliance is influenced by several factors, including tax regulation comprehension of taxpayer, service quality of tax authorities and tax audits. This study aims to determine the effect of tax regulation comprehension of taxpayer, service quality of tax authorities and tax audits of taxpayer compliance at Bulukumba Small Tax Office. The number of samples used as respondents in this study are 100 taxpayers at Bulukumba Small Tax Office. Data collection technique used is through questionnaire. Data analysis used is through multiple linear regression analysis with partial and simultaneous hypothesis tests. The results indicate that there is a positive and significant influence on tax regulation comprehension of taxpayer, service quality of tax authorities and tax audits of taxpayer compliance. This means that taxpayer compliance at Bulukumba Small Tax Office is generally influenced by tax regulation comprehension of taxpayer, service quality of tax authorities and tax audits, and the others is influenced by other factors not included in this research model.
\end{abstract}

Keywords: taxpayer compliance, tax regulation comprehension, service quality of tax authorities, tax audits 


\section{PENDAHULUAN}

Pajak merupakan salah satu sumber utama penerimaan negara. Pemungutan pajak dapat dipaksakan karena pelaksanaanya berdasarkan undang-undang. Pajak adalah kontribusi wajib kepada negara yang terutang oleh orang pribadi atau badan yang bersifat memaksaberdasarkan undang-undang, dengan tidak mendapatkan imbalan secara langsung dan digunakan untuk keperluan negara bagi sebesar-besarnya kemakmuran rakyat (Undang-Undang Nomor 28 Tahun 2007). Sebagai salah satu sumber penerimaan negara, pajak memiliki peranan yang cukup besar dalam pembangunan, baik pembangunan pemerintah pusat maupun pemerintah daerah.

Semakin tinggi penerimaan pajak maka semakin besar pula penerimaan negara, yang secara tidak langsung akan berdampak kepada semakin banyaknya pembangunan yang dilakukan oleh pemerintah sehingga akan meningkatkan kesejahteraan masyarakat. Untuk meningkatkan penerimaan pajak, maka diperlukan usaha bersama antara pemerintah dan masyarakat, termasuk para wajib pajak. Salah satu dasar penerimaan pajak sesuai target adalah kepatuhan wajib pajak (Wardani, 2018). Untuk mencapai target penerimaan pajak, perlu ditingkatkan kesadaran dan kepatuhan masyarakat wajib pajak untuk memenuhi kewajiban perpajakannya sesuai dengan ketentuan yang berlaku.
Pengertian kepatuhan pajak (tax compliance) adalah wajib pajak mempunyai kesediaan untuk memenuhi kewajiban pajaknya sesuati aturan yang berlaku tanpa perlu diadakannya pemeriksaan, investigasi seksama, peringatan ataupun ancaman, dalam penerapan sanksi baik hukum maupun administrasi (James dan Alley, 2004). Dalam penelitiannya, Gerald dan Leung (2009) menyatakan bahwa kepatuhan pajak yang tidak meningkat akan mengancam upaya pemerintah untuk meningkatkan kesejahteraan masyarakat. Wajib pajak patuh akan kewajibannya karena menganggap kepatuhan terhadap pajak adalah suatu norma (Lederman, 2003). Razak dan Adafula (2013) menyatakan bahwa mencapai tingkat kepatuhan pajak dan mempertahankan tingkat kepatuhan saat ini merupakan isu yang menjadi perhatian para pembuat kebijakan baik di negara maju maupun berkembang.

Kepatuhan wajib pajak menjadi sangat penting bagi pembangunan ekonomi negara yang dapat mempengaruhi kesejahteraan masyarakat sehingga perlu adanya motivasi dan dorongan dari fiskus sehingga dapat meningkatkan kepatuhan wajib pajak. Mengingat pentingnya peranan kepatuhan wajib pajak bagi peningkatan penerimaan pajak, maka perlu dikaji mengenai faktorfaktor yang mempengaruhi kepatuhan wajib pajak. 
Terdapat beberapa faktor yang mempengaruhi kepatuhan wajib pajak, salah satunya adalah pemahaman peraturan perpajakan. Untuk meningkatkan kepatuhan wajib pajak maka perlu adanya peningkatan pemahaman seorang wajib pajak terhadap peraturan perpajakan (Astina dan Setiawan, 2018). Dalam penelitiannya, Hardiningsih dan Yulianawati (2011) menyatakan bahwa pemahaman wajib pajak terhadap peraturan perpajakan adalah cara wajib pajak dalam memahami peraturan perpajakan yang telah ada. Hal ini diperkuat oleh Witono (2008) yang menyatakan bahwa pemahaman peraturan perpajakan akan meningkatkan kepatuhan wajib pajak. Dapat disimpulkan bahwa untuk meningkatkan kepatuhan wajib pajak, maka diperlukan adanya peningkatan pemahaman wajib pajak terhadap ketentuan peraturan perpajakan yang berlaku.

Faktor lain yang mempengaruhi kepatuhan wajib pajak adalah kualitas pelayanan fiskus. Salah satu bentuk upaya pemerintah untuk meningkatkan kepatuhan wajib pajak adalah dengan memberikan kualitas pelayanan pajak yang baik kepada para wajib pajak (Nugraheni, 2015). Dalam penelitiannya, Adhimatra dan Noviari (2018) menyatakan bahwa salah satu faktor yang dapat meningkatkan kepatuhan wajib pajak adalah pemberian layanan fiskus yang optimal bagi wajib pajak. Hal ini diperkuat oleh Supadmi (2009) yang menyatakan bahwa untuk meningkatkan kepatuhan wajib pajak dalam memenuhi kewajiban perpajakannya, kualitas pelayanan pajak harus ditingkatkan oleh aparat pajak. Dapat disimpulkan bahwa peran fiskus dalam memberikan pelayanan yang baik kepada wajib pajak diharapkan dapat meningkatkan kepatuhan wajib pajak.

Kepatuhan wajib pajak juga dipengaruhi oleh faktor lainnya, salah satunya adalah pemeriksaan pajak. Salah satu bentuk pengawasan dan pembinaan terhadap wajib pajak adalah melalui pemeriksaan, dengan demikian pemeriksaan pajak merupakan benteng penjaga agar wajib pajak tetap berada pada koridor terhadap permasalahan penghindaran pajak sebagai isu utama dalam dunia perpajakan pemeriksaan pajak merupakan pagar penjaga agar wajib pajak tetap mematuhi kewajibannya (Suhendra, 2010). Pemeriksaan pajak merupakan salah satu upaya pemerintah untuk membentuk perilaku kepatuhan Wajib Pajak orang pribadi maupun suatu badan usaha (Mandagi et al., 2014). Dalam penelitiannya, Rahayu (2011) menyatakan bahwa terdapat pengaruh pemeriksaan pajak terhadap kepatuhan wajib pajak. Hal ini diperkuat oleh Dewi dan Supadmi (2009) yang menyatakan bahwa peningkatan sistem pemeriksaan pajak yang dilakukan fiskus dapat meningkatkan kepatuhan wajib pajak. Dapat disimpulkan 
bahwa pelaksanaan pemeriksaan pajak yang baik sebagai salah satu bentuk pengawasan dan pembinaan diharapkan dapat meningkatkan kepatuhan wajib pajak.

Kantor Pelayanan Pajak Pratama Bulukumba merupakan salah satu unit kerja Direktorat Jenderal Pajak Kementerian Keuangan Republik Indonesia, yang berada langsung di bawah Kantor Wilayah Direktorat Jenderal Pajak Sulawesi Selatan, Barat dan Tenggara. Kantor Pelayanan Pajak Pratama Bulukumba memiliki tugas dan tanggung jawab salah satunya untuk melaksanakan pengadministrasian perpajakan wajib pajak yang berada di wilayah Kabupaten Bulukumba, Kabupaten Sinjai dan Kabupaten Kepulauan Selayar. Wajib pajak tersebut memiliki karakteristik yang berbeda-beda, dengan tingkat kepatuhan yang berbeda-beda pula.

Berdasarkan uraian latar belakang permasalahan di atas, maka tujuan penelitian yang diajukan adalah sebagai berikut:

1. Untuk mengetahui pengaruh pemahaman peraturan perpajakan wajib pajak secara parsial terhadap kepatuhan wajib pajak pada Kantor Pelayanan Pajak Pratama Bulukumba.

2. Untuk mengetahui pengaruh kualitas pelayanan fiskus secara parsial terhadap kepatuhan wajib pajak pada Kantor Pelayanan Pajak Pratama Bulukumba.
3. Untuk mengetahui pengaruh pemeriksaan pajak secara parsial terhadap kepatuhan wajib pajak pada Kantor Pelayanan Pajak Pratama Bulukumba.

4. Untuk mengetahui pengaruh pemahaman peraturan perpajakan wajib pajak, kualitas pelayanana fiskus dan pemeriksaan pajak secara simultan terhadap kepatuhan wajib pajak pada Kantor Pelayanan PajakPratama Bulukumba.

\section{METODE PENELITIAN}

Penelitian ini menggunakan metode penelitian eksplanatori, yaitu suatu survei yang digunakan untuk mengetahui hubungan kausal antar variabel melalui pengujian hipotesis.

Unit analisis dalam penelitian ini adalah wajib pajak pada Kantor Pelayanan Pajak Pratama Bulukumba. Responden dalam penelitian ini sebanyak 100 wajib pajak yang terdaftar pada Kantor Pelayanan Pajak Pratama Bulukumba.

Metode pengumpulan data yang digunakan sebagai instrumen dalam penelitian ini adalah kuesioner, yaitu pengumpulan data dengan menyebarkan kuesioner dengan daftar pernyataan tertutup yang diberikan kepada responden. Pengumpulan data menggunakan periode waktu cross section, dimana penelitian berlangsung selama bulan januari tahun 2019.

Variabel yang digunakan dalam penelitian ini adalah sebagai berikut: 
1. Variabel bebas yaitu pemahaman peraturan perpajakan wajib pajak, kualitas pelayanan fiskus dan pemeriksaan pajak sebagai variabel $\mathrm{X}_{1}$, variabel $\mathrm{X}_{2}$ dan variabel $\mathrm{X}_{3}$.

2. Variabel terikat yaitu kepatuhan wajib pajak sebagai variabel $\mathrm{Y}$.

Masing-masing indikator dari setiap variabel dalam penelitian ini dituangkan dalam pertanyaan atau pertanyaan dan diukur menggunakan skala likert, yaitu setiap pertanyaan atau pernyataan dari setiap variabel diberi nilai skor dari yang terendah hingga tertinggi secara berturut-turut diberikan nilai 1, $2,3,4,5$.

Pengujian kualitas instrumen masingmasing variabel dalam penelitian ini menggunakan uji validitas dan uji realibilitas.

Metode analisia data yang digunakan dalam penelitian ini menggunakan metode regresi. Dalam metode regresi biasanya ditemukan beberapa masalah asumsi klasik, oleh karena itu untuk memberikan kepastian bahwa persamaan regresi yang didapatkan dalam penelitian ini memiliki ketepatan dalam estimasi, tidak bias dan konsisten, maka perlu dilakukan uji asumsi klasik. Adapun uji asumsi klasik yang digunakan yaitu uji normalitas, uji multikolinieritas, uji autokorelasi dan uji heteroskedastisitas.

Untuk menguji pengaruh pemahaman peraturan perpajakan wajib pajak, kualitas pelayanan fiskus dan pemeriksaan pajak terhadap kepatuhan wajib pajak, digunakan analisis regresi linier berganda. Pengujian hipotesis dalam penelitian ini dilakukan dengan menggunakan uji parsial dengan uji t, uji simultan dengan uji $\mathrm{F}$ dan uji koefisien determinasi dengan koefisien determinasi $\left(\mathrm{R}^{2}\right)$.

\section{HASIL PENELITIAN}

Informasi mengenai karakteristik variabel dalam penelitian dapat dilihat dalam tabel berikut:

Tabel 1. Hasil Uji Statistik Deskriftif

\begin{tabular}{|c|c|c|c|c|c|}
\hline $\begin{array}{c}\text { Vari- } \\
\text { abel }\end{array}$ & $\mathbf{N}$ & Min & Max & Mean & $\begin{array}{c}\text { Std. } \\
\text { Deviasi }\end{array}$ \\
\hline X1 & 100 & 17 & 25 & 21,24 & 2,475 \\
\hline X2 & 100 & 12 & 25 & 18,70 & 4,272 \\
\hline X3 & 100 & 12 & 25 & 18,93 & 3,862 \\
\hline Y & 100 & 20 & 25 & 23,65 & 1,452 \\
\hline
\end{tabular}

Sumber : Hasil Pengolahan Data 2019

Tabel 1 menunjukkan bahwa variabel pemahaman peraturan perpajakan wajib pajak $\left(\mathrm{X}_{1}\right)$ memiliki nilai minimum sebesar 17 , nilai maksimum sebesar 25, rata-rata atau mean sebesar 21,24 dan standar deviasi sebesar 2,475. Hal ini menunjukkan bahwa terjadi perbedaan nilai pemahaman peraturan perpajakan wajib pajak yang diteliti dengan nilai rata-ratanya sebesar 2,475. Variabel kualitas pelayanan fiskus $\left(\mathrm{X}_{2}\right)$ memiliki nilai minimum sebesar 12, nilai maksimum sebesar 25, rata-rata atau mean sebesar 18,70 dan standar deviasi sebesar 4,272.

Hal ini menunjukkan bahwa terjadi perbedaan nilai kualitas pelayanan fiskus yang 
diteliti dengan nilai rata-ratanya sebesar 4,272. Variabel pemeriksaan pajak $\left(\mathrm{X}_{3}\right)$ memiliki nilai minimum sebesar 12, nilai maksimum sebesar 25, rata-rata atau mean sebesar 18,93 dan standar deviasi sebesar 3,862. Hal ini menunjukkan bahwa terjadi perbedaan nilai pemeriksaan pajak yang diteliti dengan nilai rata-ratanya sebesar 3,862. Variabel kepatuhan wajib pajak (Y) memiliki nilai minimum sebesar 20, nilai maksimum sebesar 25 , ratarata atau mean sebesar 23,65 dan standar deviasi sebesar 1,452. Hal ini menunjukkan bahwa terjadi perbedaan kepatuhan wajib Pajak yang diteliti dengan nilai rata-ratanya sebesar 1,452 .

Hasil uji validitas terhadap variabel bebas adalah sebagai berikut:

Tabel 2. Hasil Uji Validitas Variabel Pemahaman Perpajakan Wajib Pajak

\begin{tabular}{|c|c|c|c|}
\hline $\begin{array}{c}\text { Item } \\
\text { Pertanyaan }\end{array}$ & $\begin{array}{c}\text { Nilai } \\
\text { Pearson } \\
\text { Correlation }\end{array}$ & $\begin{array}{c}\text { Nilai } \\
\mathbf{r} \\
\text { tabel }\end{array}$ & $\begin{array}{c}\text { Kesim- } \\
\text { pulan }\end{array}$ \\
\hline $\mathrm{X} 1.1$ & 0,693 & 0,197 & Valid \\
\hline $\mathrm{X} 1.2$ & 0,684 & 0,197 & Valid \\
\hline $\mathrm{X} 1.3$ & 0,742 & 0,197 & Valid \\
\hline $\mathrm{X} 1.4$ & 0,735 & 0,197 & Valid \\
\hline $\mathrm{X} 1.5$ & 0,553 & 0,197 & Valid \\
\hline
\end{tabular}

Sumber : Hasil Pengolahan Data 2019

Tabel 3. Hasil Uji Validitas Variabel Kualitas Pelayanan Fiskus

\begin{tabular}{|c|c|c|c|}
\hline $\begin{array}{c}\text { Item } \\
\text { Pertanyaan }\end{array}$ & $\begin{array}{c}\text { Nilai } \\
\text { Pearson } \\
\text { Correlation }\end{array}$ & $\begin{array}{c}\text { Nilai } \\
\mathbf{r} \\
\text { tabel }\end{array}$ & $\begin{array}{c}\text { Kesim- } \\
\text { pulan }\end{array}$ \\
\hline X2.1 & 0,808 & 0,197 & Valid \\
\hline X2.2 & 0,852 & 0,197 & Valid \\
\hline
\end{tabular}

\begin{tabular}{|c|c|c|c|}
\hline X2.3 & 0,891 & 0,197 & Valid \\
\hline X2.4 & 0,884 & 0,197 & Valid \\
\hline X2.5 & 0,827 & 0,197 & Valid \\
\hline
\end{tabular}

Sumber : Hasil Pengolahan Data 2019

Tabel 4. Hasil Uji Validitas

Variabel Pemeriksaan Pajak

\begin{tabular}{|c|c|c|c|}
\hline $\begin{array}{c}\text { Item } \\
\text { Pertanyaan }\end{array}$ & $\begin{array}{c}\text { Nilai } \\
\text { Pearson } \\
\text { Correlation }\end{array}$ & $\begin{array}{c}\text { Nilai } \\
\mathbf{r} \\
\text { tabel }\end{array}$ & $\begin{array}{c}\text { Kesim- } \\
\text { pulan }\end{array}$ \\
\hline X3.1 & 0,825 & 0,197 & Valid \\
\hline X3.2 & 0,896 & 0,197 & Valid \\
\hline X3.3 & 0,853 & 0,197 & Valid \\
\hline X3.4 & 0,860 & 0,197 & Valid \\
\hline X3.5 & 0,779 & 0,197 & Valid \\
\hline
\end{tabular}

Sumber : Hasil Pengolahan Data 2019

Berdasarkan tabel 2, tabel 3, dan tabel 4, diperoleh gambaran bahwa uji instrumen untuk variabel bebas, yaitu pemahaman peraturan perpajakan wajib pajak $\left(\mathrm{X}_{1}\right)$, kualitas pelayanan fiskus $\left(\mathrm{X}_{2}\right)$ dan pemeriksaan pajak $\left(\mathrm{X}_{3}\right)$ menunjukkan bahwa nilai pearson correlation untuk masing-masing item pertanyaan lebih besar dari nilai r-tabel yaitu 0.197, sehingga bisa disimpulkan bahwa semua pertanyaan yang digunakan sebagai instrumen untuk variabel bebas adalah valid.

Hasil uji validitas terhadap variabel terikat adalah sebagai berikut:

Tabel 5. Hasil Uji Validitas Variabel Kepatuhan Wajib Pajak

\begin{tabular}{|c|c|c|c|}
\hline $\begin{array}{c}\text { Item } \\
\text { Pertanyaan }\end{array}$ & $\begin{array}{c}\text { Nilai } \\
\text { Pearson } \\
\text { Correlation }\end{array}$ & $\begin{array}{c}\text { Nilai } \\
\mathbf{r} \\
\text { tabel }\end{array}$ & $\begin{array}{c}\text { Kesim- } \\
\text { pulan }\end{array}$ \\
\hline Y.1 & 0,336 & 0,197 & Valid \\
\hline Y.2 & 0,206 & 0,197 & Valid \\
\hline
\end{tabular}




\begin{tabular}{|c|c|c|c|}
\hline Y.3 & 0,364 & 0,197 & Valid \\
\hline Y.4 & 0,337 & 0,197 & Valid \\
\hline Y.5 & 0,439 & 0,197 & Valid \\
\hline Y.6 & 0,364 & 0,197 & Valid \\
\hline
\end{tabular}

Sumber : Hasil Pengolahan Data 2019

Berdasarkan tabel 5 diperoleh gambaran bahwa uji instrumen untuk variabel terikat, yaitu kepatuhan wajib pajak (Y) menunjukkan bahwa nilai pearson correlation untuk masingmasing butir pernyataan lebih besar dari nilai rtabel yaitu 0.197, sehingga bisa disimpulkan bahwa semua pertanyaan yang digunakan sebagai instrumen untuk variabel terikat adalah valid.

Hasil uji reliabilitas terhadap variabel bebas dan variabel terikat adalah sebagai berikut:

Tabel 6. Hasil Uji Realibiltas

\begin{tabular}{|l|c|c|c|}
\hline \multicolumn{1}{|c|}{ Variabel } & $\begin{array}{c}\text { Nilai } \\
\text { Cronbach, } \\
\text { s Alpha }\end{array}$ & $\begin{array}{c}\text { Nilai } \\
\text { Batas } \\
\text { Alph } \\
\boldsymbol{a}\end{array}$ & $\begin{array}{c}\text { Kesim- } \\
\text { pulan }\end{array}$ \\
\hline $\begin{array}{l}\text { Pemahaman } \\
\text { Peraturan } \\
\text { Perpajakan } \\
\text { Wajib Pajak }\end{array}$ & 0,693 & 0,6 & $\begin{array}{c}\text { Reliabe } \\
1\end{array}$ \\
\hline $\begin{array}{l}\text { Kualitas } \\
\text { Pelayanan } \\
\text { Fiskus }\end{array}$ & 0,684 & 0,6 & $\begin{array}{c}\text { Reliabe } \\
1\end{array}$ \\
\hline $\begin{array}{l}\text { Pemeriksaa } \\
\text { n Pajak }\end{array}$ & 0,742 & 0,6 & $\begin{array}{c}\text { Reliabe } \\
1\end{array}$ \\
\hline $\begin{array}{l}\text { Kepatuhan } \\
\text { Wajib }\end{array}$ & 0,735 & 0,6 & Reliabe \\
Pajak
\end{tabular}

Sumber : Hasil Pengolahan Data 2019
Hasil pengujian reabilitas dari masingmasing variabel sebagaiamana terlihat pada tabel 6 menunjukkan bahwa nilai cronbach's alpha untuk masing-masing variabel bebas maupun variabel terikat lebih besar dari nilai batas alpha yaitu 0,6 , sehingga bisa disimpulkan bahwa seluruh instrumen yang digunakan untuk mengukur seluruh item dari variabel bebas yaitu pemahaman peraturan perpajakan wajib pajak $\left(\mathrm{X}_{1}\right)$, kualitas pelayanan fiskus $\left(\mathrm{X}_{2}\right)$ dan pemeriksaan pajak $\left(X_{3}\right)$ serta variabel terikat yaitu kepatuhan wajib pajak (Y) dinyatakan reliabel.

Hasil dari uji asumsi klasik adalah sebagai berikut:

Tabel 7. Hasil Uji Normalitas

\begin{tabular}{|c|c|c|c|}
\hline Model & $\begin{array}{c}\text { Kolmogorov- } \\
\text { Smirnov } Z\end{array}$ & $\begin{array}{c}\text { Asymp.Sig } \\
\text { (2-tailed) }\end{array}$ & Alpha \\
\hline 1 & 0,714 & 0,687 & 0,05 \\
\hline
\end{tabular}

Sumber : Hasil Pengolahan Data 2019

Tabel 8. Hasil Uji Multikolinieritas

\begin{tabular}{|c|c|c|}
\hline Variabel & Tolerance & VIF \\
\hline $\begin{array}{l}\text { Pemahaman Peraturan } \\
\text { Perpajakan Wajib } \\
\text { Pajak }\end{array}$ & 0,991 & 1,009 \\
\hline $\begin{array}{l}\text { Kualitas Pelayanan } \\
\text { Fiskus }\end{array}$ & 0,996 & 1,004 \\
\hline Pemeriksaan Pajak & 0,994 & 1,006 \\
\hline
\end{tabular}

Tabel 9. Hasil Uji Autokorelasi

\begin{tabular}{|c|c|c|c|}
\hline Model & $\begin{array}{c}\text { Durbin- } \\
\text { Watson }\end{array}$ & $\mathbf{d U}$ & 4-dU \\
\hline 1 & 2,376 & 1,613 & 2,387 \\
\hline
\end{tabular}

Sumber : Hasil Pengolahan Data 2019 
Tabel 10. Hasil Uji Heteroskedastisitas

\begin{tabular}{|l|c|c|}
\hline \multicolumn{1}{|c|}{ Variabel } & t & sig \\
\hline (Konstanta) & 0,005 & 0,996 \\
\hline $\begin{array}{l}\text { Pemahaman Peraturan } \\
\begin{array}{l}\text { Perpajakan Wajib } \\
\text { Pajak }\end{array}\end{array}$ & 0,641 & 0,523 \\
\hline $\begin{array}{l}\text { Kualitas Pelayanan } \\
\text { Fiskus }\end{array}$ & 1,036 & 0,304 \\
\hline Sumber : Hasil Pengon
\end{tabular}

Sumber : Hasil Pengolahan Data 2019

Hasil uji normalitas berdasarkan tabel 7 menunjukkan bahwa nilai kolmogorov-smirnov $z$ sebesar 0,714 dan nilai asymp.sig sebesar 0,687. Dari hasil tersebut diperoleh bahwa nilai asymp.sig lebih besar dari alpha yaitu 0,687 lebih besar dari 0,05, sehingga dapat disimpulkan bahwa model regresi dalam penelitian ini berdistribusi normal.

Hasil uji multikolinieritas berdasarkan tabel 8 menunjukkan bahwa untuk masingmasing variabel bebas, nilai VIF lebih kecil dari 10 dan nilai tolerance lebih besar dari 0,1 . Hal ini berarti bahwa antara variabel bebas dalam penelitian ini tidak terjadi hubungan atau tidak memiliki hubungan satu sama lainnya, sehingga dapat disimpulkan bahwa tidak terdapat multikolinieritas antar variabel bebas dalam model regresi.

Hasil uji autokorelasi berasarkan tabel 9 menunjukkan bahwa nilai Durbin-Watson adalah sebesar 2,376 berada diantara dU dan (4-dU), yaitu $1,613<2,376<2,387$. Dengan demikian, dapat disimpulkan bahwa tidak terjadi autokorelasi pada model regresi dalam penelitian ini.

Hasil uji heteroskedastisitas berdasarkan tabel 10 menunjukkan bahwa nilai sig pada masing-masing variabel bernilai lebih besar dari 0,05. Dengan demikian, dapat disimpulkan bahwa tidak terjadi gejala heteroskedastisitas dalam model regresi pada penelitian ini.

Berdasarkan hasil uji asumsi klasik dapat disimpulkan bahwa model regresi dalam penelitian ini memenuhi seluruh kriteria pengujian asumsi klasik, sehingga bisa dilanjutkan ke uji regresi linier berganda.

Hasil uji regresi linier berganda terhadap ketiga variabel bebas, yaitu pemahaman peraturan perpajakan wajib pajak $\left(\mathrm{X}_{1}\right)$, kualitas pelayanan fiskus $\left(\mathrm{X}_{2}\right)$ dan pemeriksaan pajak (X3) dapat dilihat pada tabel berikut:

Tabel 11. Hasil Pengujian Regresi Linier Berganda

\begin{tabular}{|c|c|c|c|}
\hline \multirow{2}{*}{ Variabel } & \multirow{2}{*}{ B } & \multicolumn{2}{|c|}{ Uji t } \\
\hline & & t hitung & sig \\
\hline (Konstanta) & 10,791 & 21,026 & 0,000 \\
\hline $\begin{array}{l}\text { Pemahaman } \\
\text { Peraturan } \\
\text { Perpajakan } \\
\text { Wajib Pajak }\end{array}$ & 0,290 & 14,448 & 0,000 \\
\hline $\begin{array}{l}\text { Kualitas } \\
\text { Pelayanan } \\
\text { Fiskus }\end{array}$ & 0,232 & 19,977 & 0,000 \\
\hline $\begin{array}{l}\text { Pemeriksaan } \\
\text { Pajak }\end{array}$ & 0,125 & 9,713 & 0,000 \\
\hline & & & $\mathbf{R}^{2}$ \\
\hline & F hitung & sig & $\mathbf{K}^{-2}$ \\
\hline & 255,230 & 0,000 & 0,889 \\
\hline
\end{tabular}

Sumber : Hasil Pengolahan Data 2019 
Tabel 11 menunjukkan nilai koefisien determinasi $\left(\mathrm{R}^{2}\right)$ sebesar 0,889 , yang berarti bahwa ada pengaruh sebesar 0,889 atau $88,9 \%$ dari variabel bebas, yaitu pemahaman peraturan perpajakan wajib pajak $\left(\mathrm{X}_{1}\right)$, kualitas pelayanan fiskus $\left(\mathrm{X}_{2}\right)$ dan pemeriksaan pajak $\left(\mathrm{X}_{3}\right)$ dalam menjelaskan variabel terikat yaitu kepatuhan wajib pajak (Y), sedangkan sisanya sebesar 0,111 atau $11,1 \%$ dijelaskan oleh variabel lainnya yang tidak diteliti dalam model penelitian ini.

Berdasarkan tabel 11 diperoleh bahwa persamaan regresi linier berganda untuk penelitian ini adalah sebagai berikut:

$$
Y=10,791+0,29 X 1+0,232 X 2+0,125 X 3
$$

Dari persamaan regresi tersebut, diperoleh bahwa nilai koefisien regresi pada variabel pemahaman peraturan perpajakan wajib pajak $\left(\mathrm{X}_{1}\right)$, kualitas pelayanan fiskus $\left(\mathrm{X}_{2}\right)$ dan pemeriksaan pajak $\left(\mathrm{X}_{3}\right)$ semuanya positif, artinya semua variabel bebas berpengaruh positif terhadap variabel terikat. Nilai konstanta sebesar 10,791 dapat diartikan bahwa apabila nilai pemahaman peraturan perpajakan wajib pajak $\left(\mathrm{X}_{1}\right)$, kualitas pelayanan fiskus $\left(\mathrm{X}_{2}\right)$ dan pemeriksaan pajak (X3) sama dengan nol, maka nilai kepatuhan wajib pajak (Y) cenderung meningkat sebesar 10,791. Nilai koefisien dari $\mathrm{X}_{1}$ sebesar 0,29 dapat diartikan bahwa apabilai nilai pemahaman peraturan perpajakan wajib pajak
$\left(\mathrm{X}_{1}\right)$ meningkat satu satuan, maka nilai kepatuhan wajib pajak (Y) cenderung meningkat sebesar 0,29 satuan dengan asumsi variabel bebas lainnya memiliki nilai sama dengan nol. Nilai koefisien dari $\mathrm{X}_{2}$ sebesar 0,232 dapat diartikan bahwa apabilai nilai kualitas pelayanan fiskus $\left(\mathrm{X}_{2}\right)$ meningkat satu satuan, maka nilai kepatuhan wajib pajak (Y) cenderung meningkat sebesar 0,232 satuan dengan asumsi variabel bebas lainnya memiliki nilai sama dengan nol. Nilai koefisien dari $\mathrm{X}_{3}$ sebesar 0,125 dapat diartikan bahwa apabilai nilai pemeriksaan pajak $\left(\mathrm{X}_{3}\right)$ meningkat satu satuan, maka nilai kepatuhan wajib pajak (Y) cenderung meningkat sebesar 0,125 satuan dengan asumsi variabel bebas lainnya memiliki nilai sama dengan nol.

1. Pengujian Hipotesis Secara Parsial Perhitungan koefisien regresi secara parsial dapat dilihat pada tabel 11 , dengan penjelasan sebagai berikut:

a. Variabel pemahaman peraturan perpajakan wajib pajak $\left(\mathrm{X}_{1}\right)$ dengan kepatuhan wajib pajak menunjukkan t-hitung sebesar 14,448 dengan angka sig sebesar 0,000. Karena angka sig lebih kecil dari alpha, yaitu 0,000 lebih kecil dari 0,05, hal ini berarti $\mathrm{H}_{0}$ ditolak dan $\mathrm{H}_{1}$ diterima, sehingga dapat disimpulkan bahwa faktor pemahaman peraturan perpajakan wajib pajak mempunyai 
pengaruh positif dan signifikan terhadap kepatuhan wajib pajak pada Kantor Pelayanan Pajak Pratama Bulukumba.

b. Variabel kualitas pelayanan fiskus $\left(\mathrm{X}_{2}\right)$ dengan kepatuhan wajib pajak (Y) menunjukkan t-hitung sebesar 19,977 dengan angka sig sebesar 0,000 . Karena angka sig lebih kecil dari alpha, yaitu 0,000 lebih kecil dari 0,05, hal ini berarti $\mathrm{H}_{0}$ ditolak dan $\mathrm{H}_{1}$ diterima, sehingga dapat disimpulkan bahwa faktor kualitas pelayanan fiskus mempunyai pengaruh positif dan signifikan terhadap kepatuhan wajib pajak pada Kantor Pelayanan Pajak Pratama Bulukumba.

c. Variabel pemeriksaan pajak $\left(\mathrm{X}_{3}\right)$ dengan kepatuhan wajib pajak (Y) menunjukkan t-hitung sebesar 9,713 dengan angka sig sebesar 0,000. Karena angka sig lebih kecil dari alpha, yaitu 0,000 lebih kecil dari 0,05, hal ini berarti $\mathrm{H}_{0}$ ditolak dan $\mathrm{H}_{1}$ diterima, sehingga dapat disimpulkan bahwa faktor pemeriksaan pajak mempunyai pengaruh positif dan signifikan terhadap kepatuhan wajib pajak pada Kantor Pelayanan Pajak Pratama Bulukumba.

2. Pengujian Hipotesis Secara Simultan
Tabel 11 menunjukkan bahwa nilai F-hitung sebesar 255,230 dengan angka sig sebesar 0,000. Karena angka sig lebih kecil dari alpha, yaitu 0,000 lebih kecil dari 0,05 , hal ini berarti $\mathrm{H}_{0}$ ditolak dan $\mathrm{H}_{1}$ diterima, sehingga dapat disimpulkan bahwa faktor pemahaman peraturan perpajakan wajib pajak, faktor kualitas pelayanan fiskus dan faktor pemeriksaan pajak secara bersama-sama mempunyai pengaruh positif dan signifikan terhadap kepatuhan wajib pajak pada Kantor Pelayanan Pajak Pratama Bulukumba.

\section{PEMBAHASAN}

\section{Pengaruh Pemahaman Peraturan} Perpajakan Wajib Pajak terhadap Kepatuhan Wajib Pajak pada Kantor Pelayanan Pajak Pratama Bulukumba secara parsial.

Pengaruh pemahaman peraturan perpajakan wajib pajak terhadap kepatuhan wajib pajak dihitung dengan menggunakan hasil perhitungan koefisien regresi. Dari hasil perhitungan analisis regresi yang dilakukan diperoleh koefisien regresi pemahaman peraturan perpajakan wajib pajak $\left(\mathrm{X}_{1}\right)$ sebesar 0,290. Angka koefisien regresi tersebut bernilai positif terhadap kepatuhan wajib pajak (Y). Dengan demikian, dapat dikatakan bahwa semakin baik atau semakin tinggi 
pemahaman peraturan perpajakan wajib pajak, maka semakin tinggi tingkat kepatuhan wajib pajak.

Hasil penelitian ini sejalan dengan penelitian yang dikemukakan oleh Wardani dan Wati (2018) bahwa pemahaman peraturan perpajakan berpengaruh positif dan signifikan terhadap kepatuhan wajib pajak. Hasil penelitian ini tidak sejalan dengan penelitian yang dilakukan oleh Susanto (2013) yang menyatakan bahwa pemahaman peraturan perpajakan tidak berpengaruh secara signifikan terhadap kepatuhan wajib pajak, tetapi didukung oleh penelitian yang dilakukan oleh Siregar et al. (2012), Noviyanti et al. (2015), Tambun (2016) serta Naufal dan Setiawan (2018) yang menunjukkan bahwa pemahaman peraturan perpajakan mempunyai pengaruh signifikan terhadap kepatuhan wajib pajak.

2. Pengaruh Kualitas Pelayanan Fiskus terhadap Kepatuhan Wajib Pajak pada Kantor Pelayanan Pajak Pratama Bulukumba secara parsial.

Pengaruh kualitas pelayanan fiskus terhadap kepatuhan wajib pajak dihitung dengan menggunakan hasil perhitungan koefisien regresi. Dari hasil perhitungan analisis regresi yang dilakukan diperoleh koefisien regresi kualitas pelayanan fiskus
$\left(\mathrm{X}_{2}\right)$ sebesar 0,232. Angka koefisien regresi tersebut bernilai positif terhadap kepatuhan wajib pajak (Y). Dengan demikian, dapat dikatakan bahwa semakin baik kualitas pelayanan fiskus, maka semakin tinggi tingkat kepatuhan wajib pajak.

Hasil penelitian ini sejalan dengan penelitian yang dikemukakan oleh Noviyanti et al. (2015) bahwa kualitas pelayanan fiskus berpengaruh positif dan signifikan terhadap kepatuhan wajib pajak. Hasil penelitian ini tidak sejalan dengan penelitian yang dilakukan oleh Tirada (2013) bahwa kualitas pelayanan fiskus tidak berpengaruh secara signifikan terhadap kepatuhan wajib pajak, tetapi didukung oleh penelitian yang dilakukan oleh Prajogo (2013), Nugraheni dan Purwanto (2015) serta Astina dan Setiawan (2018) yang menunjukkan bahwa kualitas pelayanan fiskus mempunyai pengaruh signifikan terhadap kepatuhan wajib pajak.

\section{Pengaruh Pemeriksaan Pajak terhadap} Kepatuhan Wajib Pajak pada Kantor Pelayanan Pajak Pratama Bulukumba secara parsial.

Pengaruh kualitas pelayanan fiskus terhadap kepatuhan wajib pajak dihitung dengan menggunakan hasil perhitungan koefisien regresi. Dari hasil perhitungan 
analisis regresi yang dilakukan diperoleh koefisien regresi pemeriksaan pajak $\left(\mathrm{X}_{3}\right)$ sebesar 0,125. Angka koefisien regresi tersebut bernilai positif terhadap kepatuhan wajib pajak (Y). Dengan demikian, dapat dikatakan bahwa semakin baik pelaksanaan pemeriksaan pajak, maka semakin tinggi tingkat kepatuhan wajib pajak.

Hasil penelitian ini sejalan dengan penelitian yang dikemukakan oleh Rahayu (2011) bahwa pemeriksaan pajak berpengaruh positif dan signifikan terhadap kepatuhan wajib pajak. Hasil penelitian ini tidak sejalan dengan penelitian yang dilakukan oleh Amanda et al. (2014) bahwa pemeriksaan pajak tidak berpengaruh secara signifikan terhadap kepatuhan wajib pajak, tetapi didukung oleh penelitian yang dilakukan oleh Anggraini et al. (2016), Tatiana dan Noch (2016), Palupi dan Harianti (2017), Assa et al. (2018) serta Wahda dan Yuniati (2018) yang menunjukkan bahwa pemahaman peraturan perpajakan mempunyai pengaruh signifikan terhadap kepatuhan wajib pajak.

\section{Pengaruh Pemahaman Peraturan} Perpajakan Wajib Pajak, Kualitas Pelayanan Fiskus dan Pemeriksaan Pajak terhadap Kepatuhan Wajib

\section{Pajak pada Kantor Pelayanan Pajak} Pratama Bulukumba secara simultan.

Pengaruh pemahaman peraturan perpajakan wajib pajak, kualitas pelayanan fiskus dan pemeriksaan pajak secara simultan terhadap kepatuhan wajib pajak dihitung dengan menggunakan hasil perhitungan koefisien determinasi. Dari hasil perhitungan analisis regresi yang dilakukan diperoleh koefisien determinasi sebesar 0,889 atau 88,9\%. Angka koefisien determinasi tersebut menunjukkan adanya pengaruh positif pada faktor pemahaman peraturan perpajakan wajib pajak, kualitas pelayanan fiskus dan pemeriksaan pajak secara simultan dalam menjelaskan kepatuhan wajib pajak sebesar 0,889 atau $88,9 \%$, sedangkan sisanya sebesar 0,111 atau $11,1 \%$ dijelaskan oleh variabel lain yang tidak diteliti dalam penelitian ini.

Hasil penelitian ini menunjukkan bahwa kepatuhan wajib pajak pada Kantor Pelayanan Pajak Pratama Bulukumba akan meningkat seiring dengan meningkatnya pemahaman peraturan perpajakan wajib pajak dan semakin baiknya kualitas pelayanan yang diberikan oleh fiskus dalam hal ini aparat pajak pada Kantor Pelayanan Pajak Pratama Bulukumba. Selain itu juga dipengaruhi dengan semakin baiknya pelaksanaan pemeriksaan pajak. Pemeriksaan pajak 
perlu dilaksanakan sebagai salah satu bentuk pengawasan untuk menguji kepatuhan wajib pajak.

Untuk meningkatkan pemahaman peraturan perpajakan wajib pajak, fiskus pada Kantor Pelayanan Pajak Pratama Bulukumba sebaiknya meningkatkan pelaksanaan kegiatan sosialisasi perpajakan sebagai upaya untuk menyebarluaskan informasi mengenai hak dan kewajiban wajib pajak serta peraturanperaturan terbaru yang berkaitan dengan peraturan perpajakan.

Seiring dengan perkembangan ilmu pengetahuan dan teknologi, kebijakan mengenai peraturan perpajakan mengalami beberapa perubahan mengikuti perkembangan tersebut. Oleh karena itu, fiskus pada Kantor Pelayanan Pajak Pratama Bulukumba juga harus aktif dalam melaksanakan sosialisasi kepada wajib pajak, baik dengan cara bertemu langsung dengan wajib pajak maupun sosialisasi melalui media cetak, media elektronik, atau media lain yang dimiliki oleh Kantor Pelayanan Pajak Pratama Bulukumba. Dengan semakin efektifnya pelaksanaan sosialisasi perpajakan oleh fiskus pada Kantor Pelayanan Pajak Pratama Bulukumba, maka pemahaman peraturan perpajakan wajib pajak juga akan semakin meningkat.
Untuk mewujudkan terciptanya pelayanan fiskus yang berkualitas kepada wajib pajak, fiskus pada Kantor Pelayanan Pajak Pratama Bulukumba sebaiknya selalu memberikan pelayanan prima kepada wajib pajak, baik wajib pajak yang datang langsung ke Kantor Pelayanan Pajak Pratama Bulukumba maupun wajib pajak yang mengajukan permohonan pelayanan melalui saluran elektronik atau saluran lain yang dimiliki oleh Kantor Pelayanan Pajak Pratama Bulukumba. Fiskus juga harus memperhatikan beberapa aspek, meliputi jangka waktu penyelesaian permohonan wajib pajak, keberadaan ruang konsultasi yang nyaman, serta kemudahan dalam mengakses informasi perpajakan pada Kantor Pelayanan Pajak Pratama Bulukumba. Dengan terciptanya kondisi tersebut pada Kantor Pelayanan Pajak Pratama Bulukumba, maka kualitas pelayanan fiskus pada Kantor Pelayanan Pajak Pratama Bulukumba akan semakin meningkat.

Untuk mewujudkan pemeriksaan pajak yang baik dan efektif, fiskus dalam hal ini pemeriksa pajak pada Kantor Pelayanan Pajak Pratama Bulukumba sebaiknya dalam menjalankan proses pemeriksaan pajak selalu memperhatikan tahapan-tahapan pemeriksaan sesuai 
dengan peraturan peundang-undangan yang berlaku di bidang perpajakan. Pemeriksa pajak sebaiknya dibekali dengan kemampuan analisis yang baik, pengetahuan perpajakan dan akutansi, serta pengetahun mengenai proses bisnis wajib pajak. Pemeriksa Pajak juga harus memperhatikan kualitas hasil pemeriksaan, sehingga temuan pemeriksaan yang dihasilkan dapat dipertanggungjawabkan dan tidak dilakukan upaya hukum oleh wajib pajak. Pemeriksa pajak juga sebaiknya selalu menjaga integritas dalam melaksanakan tugas. Dengan terciptanya kondisi tersebut, maka pemeriksaan pajak pada Kantor Pelayanan Pajak Pratama Bulukumba akan berjalan dengan baik dan efektif sesuai dengan peraturan perundang-undangan yang berlaku di bidang perpajakan.

Dengan semakin tingginya tingkat pemahaman peraturan perpajakan wajib pajak, dan semakin tingginya kualitas pelayanan fiskus, serta dengan semakin baiknya pelaksanaan pemeriksaan pajak, maka akan semakin tinggi pula kepatuhan wajib pajak pada Kantor Pelayanan Pajak Pratama Bulukumba.

\section{KESIMPULAN DAN SARAN}

Berdasarkan hasil penelitian dan pembahasan diperoleh kesimpulan bahwa pemahaman peraturan perpajakan wajib pajak, kualitas pelayanan fiskus dan pemeriksaan pajak berpengaruh positif terhadap kepatuhan wajib pajak pada Kantor Pelayanan Pajak Pratama Bulukumba, baik secara parsial maupun secara simultan. Adapun saran yang bisa diberikan dalam penelitian ini adalah saran kepada wajib pajak, fiskus dan penelitian selanjutnya.

Bagi wajib pajak, disarankan untuk meningkatkan pemahaman peraturan perpajakan, baik dengan menambah referensi melalui aktif berkomunikasi dengan pihak fiskus pada kantor pajak, maupun dengan mencari atau mengakses informasi peraturan perpajakan yang disediakan fiskus melalui media online. Bagi fiskus pada Kantor Pelayanan Pajak Pratama Bulukumba, disarankan untuk selalu meningkatkan pelaksanaan kegiatan sosialisasi kepada wajib pajak dalam rangka meningkatkan pemahaman peraturan perpajakan wajib pajak.

Fiskus juga disarankan agar selalu memberikan pelayanan yang prima kepada wajib pajak, karena dengan adanya pelayanan prima yang berkualitas dari fiskus kepada wajib pajak akan mampu meningkatkan kepatuhan wajib pajak. Selain itu juga 
disarankan agar fiskus tetap melaksanakan pemeriksaan pajak secara konsisten dan merata sebagai sarana untuk menguji kepatuhan wajib pajak dengan mengacu pada ketentuan peraturan perpajakan yang berlaku. Bagi penelitian selanjutnya, disarankan untuk melakukan penelitian dengan menambah variabel lain yang tidak digunakan dalam penelitian ini, ataupun dengan memperluas ruang lingkup penelitian dengan menggunakan sampel dari Kantor Pelayanan Pajak lainnya yang dapat digunakan sebagai sampel.

\section{REFERENSI}

Adhimatra, A.A.G. Wisnu dan N. Noviari. 2018. Faktor Yang Memengaruhi Kepatuhan Wajib Pajak Orang Pribadi Pada Kantor Pelayanan Pajak Pratama Denpasar Timur. E-Jurnal Akuntansi Universitas Udayana. 25 (1). p 711-744 [online].

Amanda, C. Pradisti, D. Rifa dan A.F. Minovia. 2014. pengaruh kesadaran wajib pajak, sanksi pajak, pelayanan fiskus, dan pemeriksaan pajak terhadap kepatuhan wajib pajak orang pribadi di kota padang. Jurnal Fakultas Ekonomi Universitas Bung Hatta. 4 (1). p 1-10 [online].

Anggraini, D. Setya, M.A. Musadieq dan Dwiatmanto. 2016. Efektivitas Pelaksanaan Pemeriksaan Pajak Dalam Rangka Meningkatkan Penerimaan Pajak (Studi Pada Kantor Pelayanan Pajak Pratama Malang Selatan). Jurnal Perpajakan (JEJAK). 8 (1). p 1-15 [online].
Assa, J. Reinhart, L. Kalangi dan W. Pontoh. 2018. Pengaruh Pemeriksaan Pajak Dan Sanksi Perpajakan Terhadap Kepatuhan Wajib Pajak Pada Kantor Pelayanan Pajak Pratama Manado. Jurnal Riset Akuntansi Going Concern. 13(4). p 516522 [online].

Astina, I.P. Surya dan P.E. Setiawan. 2018. Pengaruh Pemahaman Peraturan Perpajakan, Kualitas Pelayanan Fiskus dan Kesadaran Wajib Pajak Terhadap Tingkat Kepatuhan WPOP. E-Jurnal Akuntansi Universitas Udayana. 23(1). p 1-30 [online].

Dewi, C. Shinta dan N.L. Supadmi. 2014. Pengaruh Pemeriksaan Pajak, Kesadaran, Kualitas Pelayanan Pada Tingkat Kepatuhan Wajib Pajak Badan. E-Jurnal Akuntansi Universitas Udayana. 9 (2). p 505-514 [online].

Hardiningsih, Pancawati dan N. Yulianawati. 2011. Faktor-Faktor yang Mempengaruhi Kemauan Membayar Pajak. Jurnal Dinamika Keuangan dan Perbankan. 3 (1). p 126-142 [online].

Mandagi, Chorras, H. Sabijono dan V. Tirayoh. 2014. Pengaruh Pemeriksaan Pajak Terhadap Tingkat Kepatuhan Wajib Pajak Badan Dalam Memenuhi Kewajiban Perpajakannya Pada KPP Pratama Manado. Jurnal EMBA. 2 (3). p 1665-1674 [online].

Naufal, M. Faris dan P.E. Setiawan. 2018. Pengaruh Sosialisasi Perpajakan, Pemahaman Prosedur Perpajakan, Umur, Jenis Pekerjaan Terhadap Kepatuhan Wajib Pajak Orang Pribadi. E-Jurnal Akuntansi Universitas Udayana. 25 (1). p 241-271 [online].

Nugraheni, A. Dewi dan A. Purwanto. 2015. Faktor-Faktor Yang Mempengaruhi Kepatuhan Wajib Pajak Orang Pribadi (Studi Empiris Pada Wajib Pajak di 
Kota Magelang). Diponegoro Journal Of Accounting. 4 (3). p 1-14 [online].

Noviyanti, Siska, R. Effendi dan C. Yunita. 2015. Pengaruh Kesadaran Wajib

Pajak, Pengetahuan dan Pemahaman Peraturan Perpajakan, Kualitas Pelayanan dan Ketegasan Sanksi Perpajakan Terhadap Kepatuhan WPOP (Studi Kasus KPP Pratama Ilir Barat Palembang). Jurnal Akuntansi STIE MDP Palembang. p 1-12 [online].

Palupi, D. Yekti dan E. Harianti. 2017. Pengaruh Pemeriksaan dan Penagihan Pajak Terhadap Kepatuhan Wajib Pajak dengan Informasi Tren Media sebagai Variabel Moderating (Studi Kasus KPP Pratama Jakarta Kebayoran Baru Tiga). Jurnal InFestasi. 13 (1). p 285-296 [online].

Prajogo, J. Nidya. 2013. Pengaruh Tingkat Pemahaman Peraturan Pajak Wajib pajak, Kualitas Pelayanan Petugas Pajak, dan Persepsi Atas Sanksi Perpajakan Terhadap Kepatuhan Wajib pajak UMKM di Wilayah Sidoarjo. Tax \& Accounting Review. 3 (2). p 1-12 [online].

Rahayu, Dwi. 2011. Analisis pengaruh pemeriksaan pajak terhadap kepatuhan wajib pajak pada Kantor Pelayanan Pajak Pratama Semarang Selatan. Jurnal Ekonomi Manajemen Akuntansi. 18 (30). p 1-15 [online].

Siregar, Y. Anita, Saryadi, dan S. Listyorini. 2012. Pengaruh Pelayanan Fiskus dan Pengetahuan Perpajakan terhadap Kepatuhan Wajib Pajak. Jurnal Ilmu Administrasi Bisnis. 1 (1). $p$ 1-9 [online].

Suhendra, E. Susy. 2010. Pengaruh Tingkat Kepatuhan Wajib Pajak Badan
Terhadap Peningkatan Penerimaan Pajak Penghasilan Badan. Jurnal Ekonomi Bisnis Universitas Gunadarma. 15 (1). p 58-65 [online].

Supadmi, N. Luh. 2009. Meningkatkan Kepatuhan Wajib Pajak Melalui Kualitas Pelayanan. Audi Jurnal Akuntansi dan Bisnis. 4 (2). p 214-219 [online].

Susanto, J. Novia. 2013. Pengaruh Persepsi Pelayanan Pajak, Persepsi Pengetahuan Wajib Pajak, dan Persepsi Pengetahuan Korupsi Terhadap Kepatuhan. Jurnal Ilmiah Mahasiswa Universitas Surabaya CALYPTRA. 2 (1). p 1-17 [online].

Tambun, Sihar. 2016. Anteseden Kepatuhan Wajib Pajak Orang Pribadi dan Moderasi Sosialisasi Perpajakan. Jurnal Media Akuntansi Perpajakan. 1 (1). p 26-40 [online].

Tatiana, N. Dein dan M.Y. Noch. 2016. Pengaruh Jumlah Pemeriksaan Pajak, Sanksi Perpajakan, dan Sikap Fiskus terhadap Penerimaan Pajak Penghasilan dengan Kepatuhan Wajib Pajak sebagai Variabel Intervening pada KPP Pratama Jayapura. Jurnal Manajemen dan Akuntansi Future. p 1-14 [online].

Tirada, T. A.M. 2013. Kesadaran Perpajakan, Sanksi Pajak, Sikap Fiskus Terhadap Kepatuhan Wajib Pajak Orang Pribadi Di Kabupaten Minahasa Selatan. Jurnal EMBA. 1 (3). p 999-1008 [online].

Undang-Undang Republik Indonesia Nomor 28 Tahun 2007 Perubahan Ketiga Atas Undang-Undang Nomor 6 Tahun 1983 Tentang Ketentuan Umum dan Tata Cara Perpajakan. 17 Juli 2007. Lembaran Negara Republik Indonesia Tahun 2007 Nomor 85. Jakarta. 
Wahda, N.S. Rohmatul, A. Bagianto dan Yuniati. 2018. Pengaruh Pemeriksaan Pajak Terhadap Kepatuhan Wajib Pajak Dan Dampaknya Terhadap Efektivitas Penerimaan Pajak Penghasilan Badan. Jurnal Ilmiah Manajemen dan Akuntansi. 2 (2). p 115-143 [online].

Wardani, D. Kusuma dan E. Wati. 2018. Pengaruh Sosialisasi Perpajakan
Terhadap Kepatuhan Wajib Pajak Dengan Pengetahuan Perpajakan Sebagai Variabel Intervening (Studi Pada Wajib Pajak Orang Pribadi Di KPP Pratama Kebumen). Jurnal Nominal. 7 (1). p 33-54 [online].

Witono, Banu. 2008. Peranan Pengetahuan Pajak pada Kepatuhan Wajib Pajak. Jurnal Akuntansi dan Keuangan 7 (2). p 196-208 [online]. 